\title{
Research on Filter Rod Loose Quality of Double Channel Forming Machine Based on Apriori Algorithm of Interestingness
}

\author{
Min Zhang, Liming Zhu* and Yumin Wang \\ China Tobacco Zhejiang Industrial Co. LTD., Hangzhou, China \\ ${ }^{*}$ Corresponding author
}

\begin{abstract}
Double channel forming machine opening quality data by sampling and conversion into the mining of association rules based on Apriori algorithm, correctness verification and quality deviation setting parameters, makes the equipment in adjusting the parameters set to drive the delivery index get reliable performance.
\end{abstract}

Keywords-interest degree; APRIORI; double channel; filter rod forming machine

\section{INTRODUCTION}

Double channel forming machine is the production equipment of filter rod, is a kind of high speed and super high speed rolling equipment for molding equipment, which loosing raw materials of filter rod--two cellulose acetate tow, on the loose quality correlation can be found between equipment and production quality, contribute to the optimization and stability of the equipment. The loosening machine is mainly composed of tow guiding device and independent opener which stretching and fluffing of two acetate fiber tow. Degree of loosening will not only affect the quality of the direct filter rod, but also affect the sensory quality and product stability of cigarettes. The loosening of the filter rod consists mainly of three steps.

1. Tow input: make the tow out of the package smoothly.

2. Prestretch of the silk bundle: make the tow stretch out in a number of positions, and the fiber bundles are separated so that the fiber tow can be supplied and processed evenly;

3. Tow stretch and relaxation: the tow is extracted from the tow package and transmitted through the machine, and the tow is loosened and relaxed through the different load ratio and speed of the roller set.

In the process of equipment loosening and solidification, the research of the degree of loose and the quality of filter rod can be very important in the process of equipment commissioning and production. The research on the parameter setting process and the quality of filter rod is an important topic at present.

\section{APRIORI ALGORITHM}

Apriori algorithm is one of the most basic idea of mining association rules of frequent itemsets algorithm, the algorithm effect is[1]: using the recursive method to find all frequent sets, and then generate strong association rules by the frequency set, these rules must satisfy the minimum support degree and confidence degree. Once these rules are generated, only those rules that are larger than the given minimum credibility are left behind.

The Apriori algorithm is composed of two steps: connection and pruning.

Connection: in order to find $\mathrm{L}_{\mathrm{k}}$, a collection of candidate $\mathrm{K}$ item sets is generated through $\mathrm{L}_{\mathrm{k}-1}$ connection with itself, and the candidate $\mathrm{K}$ item set is recorded as $\mathrm{C}_{\mathrm{k}}$.

The two elements in $\mathrm{L}_{\mathrm{k}-1}, \mathrm{~L}_{1}$ and $\mathrm{L}_{2}$, can perform connection operations:

$\mathrm{C}_{\mathrm{k}}$ is a superset of $\mathrm{L}_{\mathrm{k}}$ namely, its members may not be frequent, but all $\mathrm{k}$ - frequent sets in $\mathrm{C}_{\mathrm{k}}$. So can get $\mathrm{L}_{\mathrm{k}}$ by scanning the database by calculating the support of each k- item set.

Pruning: if a subset (k-1) of a candidate $\mathrm{K}$ itemset $\mathrm{Ck}$ is not in $\mathrm{L}_{\mathrm{K}-1}$, then the candidate is not likely to be frequent, so it can be deleted from $\mathrm{C}_{\mathrm{k}}$ and get the compressed $\mathrm{C}_{\mathrm{k}}$.

Pseudo-code of Apriori algorithm:

The D: object database;

The Min_sup: minimum support threshold.

Output: frequent itemsets in L:D.

Method:

$\mathrm{L}_{1}=$ find_frequent_1-itemsets(D); for $\left(\mathrm{k}=2 ; \mathrm{L}_{\mathrm{k}-1} !=\not \subset ; \mathrm{k}++\right)\{$

$\mathrm{C}_{\mathrm{k}}=$ apriori_gen $\left(\mathrm{L}_{\mathrm{k}-1}\right)$;

For each transaction $\mathrm{t} \in \mathrm{D}\{/ /$

Scanning D for counting $\mathrm{Ct}=\operatorname{subset}\left(\mathrm{C}_{\mathrm{k}}, \mathrm{t}\right) ; / /$ Get a subset of $\mathrm{T}$, they are candidates for each candidate $\mathrm{c} \in \mathrm{C}$; C.count ++ ;

\} $\mathrm{L}_{\mathrm{k}}=\{\mathrm{c} \in \mathrm{C} \mid \mathrm{c} . \mathrm{count}>=$ min_stp $\}$ \} return $\mathrm{L}=\mathrm{U}_{\mathrm{k}} \mathrm{L}_{\mathrm{k}}$

\section{PROBlems of THE APRIORI AlgorithM}

Interest degree and confidence level set to mine meaningful association rules from massive data. However, the algorithm has the following problems in practical application. 
(1) to excavate the strong association rules that have a gap with the reality. For example, in the application of electronic medical record data analysis [2]

(2) the database scan level is huge. In many studies, it has been concerned about this. Various improvement methods and measures have been put forward to improve its executability and reduce expenses.

Therefore, many scholars have proposed the Apriori algorithm based on the degree of interest, and the basic principles are as follows:

Association Rules: the formulae of association rules are described as: set up $\mathrm{I}=\left\{\mathrm{i}_{1}, \mathrm{i}_{2}, \ldots, \mathrm{i}_{\mathrm{m}}\right\}$ is a collection of $\mathrm{m}$ different items, and D is a set of transactions for I, where each transaction $\mathrm{T}$ contains a number of items $\mathrm{I}_{1}, \mathrm{I}_{2}$, and... $\mathrm{I}_{\mathrm{K}}$, each transaction item is recorded as TID.

Support [3]: defined as Support $(\mathrm{X})=\operatorname{occur}(\mathrm{X}) / \operatorname{count}(\mathrm{D})$ $=\mathrm{P}(\mathrm{X})$.

Confidence[3]: is defined as conf $(\mathrm{X}->\mathrm{Y})=\operatorname{supp}(\mathrm{X}, \mathrm{Y}) /$ $\operatorname{supp}(\mathrm{X})=\mathrm{P}(\mathrm{Y} \mid \mathrm{X})$.

The interestingness of association rules is described in rule sets of items such as $X$ are set to another degree of correlation between $Y$, denoted as $X=>Y$, if the $X=>Y$ rule interestingness value is greater, the greater the tightness is $X=>Y$;

The specific description of the algorithm is [2]:

If $\mathrm{P}(\mathrm{XY})=\mathrm{P}(\mathrm{X}) \mathrm{P}(\mathrm{Y})$ means that the item set $\mathrm{X}$ is independent of the item set $\mathrm{Y}$; if $\mathrm{P}(\mathrm{XY})=\mathrm{P}(\mathrm{X})$ - $\mathrm{P}(\mathrm{Y})$ means that the event $\mathrm{X}$ and $\mathrm{Y}$ is related events, the two are not independent to each other. The association rules $\mathrm{X} Y$ excavated, set $\mathrm{X}$ and $\mathrm{Y}$ set interest degree:

$$
\begin{aligned}
& \mathrm{RI}(\mathrm{X} \mathrm{Y})=\mathrm{P}(\mathrm{XY}) \\
& \mathrm{P}(\mathrm{X}) \mathrm{P}(\mathrm{Y})
\end{aligned}
$$

When $\mathrm{RI}>1$, it is shown that the item set $\mathrm{X}$ is positively related to the item set $\mathrm{Y}$, and the occurrence of $\mathrm{X}$ will increase the probability of the occurrence of $\mathrm{Y}$.

When $\mathrm{RI}<1$, it is shown that the item set $\mathrm{X}$ is negatively correlated with the item set $\mathrm{Y}$, and the occurrence of $\mathrm{X}$ will reduce the probability of the occurrence of $Y$.

When $\mathrm{RI}=1$, it is shown that the item set $\mathrm{X}$ is independent of the item set XY, and there is no correlation between $\mathrm{X}$ and $\mathrm{Y}$.

\section{LOOSING QUALITY VERIFICATION MODEL OF FILTER BAR APRIORI AlgORITHM BASED ON INTEREST DEGREE}

Research purpose: The research is mainly about the relationship between the set value of the equipment and the quality of the final production, especially on the weight, draw resistance and hardness of the filter rod, by analyzing and mining data association, the information excavated is of great reference value in the decision-making process of small to big parameter setting, whether the equipment debugging is qualified or not.

Work flow module: data collection, data preprocessing, association rules mining, judgment module, equipment adjustment;
Equipment sampling: sampling through the front and rear channels. The sample can be taken in many groups, and each group can take more than one.

Filter bar inspection: through the inspection of the sample product, the results of the detection into the form;

The data transformation and elimination, the obtained data are converted to the algorithm model to calculate the value, and the special data are eliminated.

From the interest based Apriori algorithm calculation model, the concrete conclusions are obtained. After verifying the conclusion of module validation, the conclusions are fed back to the equipment, and the parameters are adjusted. All the processes are referred to figure 1 .

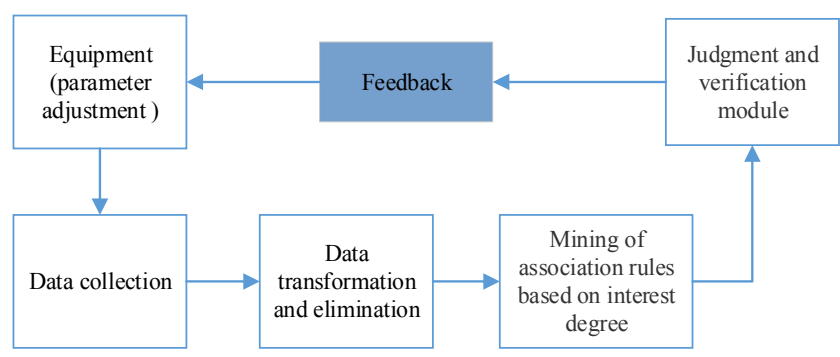

FIGURE I. PARAMETER ADJUSTMENT MODEL OF APRIORI ALGORITHM BASED ON INTEREST DEGREE

In the process of loosing and forming, there are four values of indicators represent the key indicators in the quality test, Save in the database as Table 1.

\section{TABLE I. KEY INDEX PARAMETER}

\begin{tabular}{|l|c|c|}
\hline \multicolumn{1}{|c|}{ Field name } & Data type & length \\
\hline Expansion degree & Char & 10 \\
\hline draw resistance average value & float & 4 \\
\hline Weight average & Float & 4 \\
\hline Hardness average & float & 4 \\
\hline
\end{tabular}

The effect of loosening is mainly on the absorption and filling of the tow. The channel of filter rod is sampled, and the front and rear channels are taken 15 groups, each group is 20 , and the resistance and weight are detected. The test results of $100 \mathrm{~m}$ and $150 \mathrm{~mm}$ for two stages of air loosening in the front and back channels are shown in Table 2 .

TABLE II. TEST RESULTS OF 100M AND 150MM FOR TWO STAGES

\begin{tabular}{|c|c|c|c|c|}
\hline & \multicolumn{2}{|c|}{ sample name } & $\begin{array}{c}\text { ITEM } \\
\text { average }\end{array}$ & $\begin{array}{c}\text { ITEM } \\
\text { average }\end{array}$ \\
\hline & \multicolumn{2}{|c|}{ Loose width (mm) } & 100 & 150 \\
\hline \multirow{3}{*}{$\begin{array}{l}\text { The Front } \\
\text { Channel }\end{array}$} & \multicolumn{2}{|c|}{$\begin{array}{l}\text { Draw resistance average } \\
\text { value }(\mathrm{mmH} 2 \mathrm{O})\end{array}$} & 262.8 & 262.09 \\
\hline & Weight & average $(g)$ & 0.71 & 0.71 \\
\hline & Hardness & average $(\%)$ & 86.2 & 86.19 \\
\hline \multirow{3}{*}{$\begin{array}{l}\text { The Rear } \\
\text { Channel }\end{array}$} & \multicolumn{2}{|c|}{ raw resistance average value $\left(\mathrm{mmH}_{2} \mathrm{O}\right)$} & 255.5 & 260.7 \\
\hline & Weight & average $(g)$ & 0.71 & 0.708 \\
\hline & Hardness & Average(\%) & 86.18 & 87.08 \\
\hline
\end{tabular}
OF AIR LOOSENING IN THE FRONT AND BACK 
Data transformation: transform the specific data detection value into the system measurable and the specific value that the model can use, so we transform the data of Table II into machine operation language. Such as table 3 , set up the resistance average 262.1 positive and negative 1 to $\mathrm{A}$, more than 259.1 and less than 260.1 , or the value more than 262.1 and less than 263.1 is set to $\mathrm{B}$, the value more than 263.1 or less than 259.1 is set to C; set up weight average 0.7 positive and negative 0.05 to $D$, the value more than 0.69 and less than 0.695 , or more than 0.705 and less than 0.71 is set to $E$, the value more than 0.71 or less than 0.69 is set to F; set up hardness average 86.2 positive and negative 0.1 to $\mathrm{G}$, the value more than 86.0 and less than 86.1 , or the value more than 86.3 and less than 86.4 is set to $\mathrm{H}$, or more than 86.4 and less than 86.0 is set to I. So put the data of table 2 into table 3.

TABLE III. CONVERSION DATA OF TABLE 2.

\begin{tabular}{|c|c|c|}
\hline Sample & ITEM & ITEM \\
\hline A & 0 & 1 \\
\hline B & 1 & 0 \\
\hline C & 0 & 0 \\
\hline D & 1 & 1 \\
\hline E & 0 & 0 \\
\hline F & 0 & 0 \\
\hline G & 1 & 1 \\
\hline H & 0 & 0 \\
\hline I & 0 & 0 \\
\hline A & 0 & 1 \\
\hline B & 0 & 0 \\
\hline C & 1 & 0 \\
\hline D & 1 & 1 \\
\hline E & 0 & 0 \\
\hline F & 0 & 0 \\
\hline G & 1 & 0 \\
\hline H & 0 & 0 \\
\hline I & 0 & 1 \\
\hline
\end{tabular}

Through the Apriori algorithm based on the interest degree, the experimental data from the test data are used as the source data, and the verification test model is verified.

Through the preliminary statistics of the data collection samples and the threshold used in the experiment, the minimum support degree (min_support) is $10 \%$, the minimum confidence level (min_confident) is 50\% and the interest threshold (RI) is 0.8 . In the opening width $100 \mathrm{MM}$ and $150 \mathrm{MM}$ test. The loosen width is defined as T100, T150, draw resistance value as R, weight as $\mathrm{W}$, and hardness as $\mathrm{Y}$. When the association rule of the loosen channel quality is the same as the association rule of the posterior track, we can see that the Apriori algorithm based on interest is used to mine the relevant rules.
TABLE IV. THE APRIORI ALGORITHM USING THE INTEREST THRESHOLD

\begin{tabular}{|c|c|c|c|c|c|c|}
\hline $\begin{array}{c}\text { Associati } \\
\text { on rules }\end{array}$ & $\mathrm{T} 100->\mathrm{R}$ & $\mathrm{T} 100>\mathrm{W}$ & $\mathrm{T} 100->\mathrm{Y}$ & $\mathrm{T} 150->\mathrm{R}$ & $\mathrm{T} 150>\mathrm{W}$ & $\mathrm{T} 150>\mathrm{Y}$ \\
\hline $\begin{array}{c}\text { Support } \\
\text { degree }\end{array}$ & 0.53 & 0.13 & 0.25 & 0.62 & 0.12 & 0.24 \\
\hline $\begin{array}{c}\text { Confiden } \\
\text { t degree }\end{array}$ & $89.12 \%$ & $52.13 \%$ & $50.65 \%$ & $92.03 \%$ & $56.00 \%$ & $60.65 \%$ \\
\hline $\begin{array}{c}\text { Interest } \\
\text { degree }\end{array}$ & 1.04 & 0.3 & 0.2 & 0.99 & 0.3 & 0.2 \\
\hline $\begin{array}{c}\text { Actual } \\
\text { conform } \\
\text { ation of } \\
\text { the front } \\
\text { channel }\end{array}$ & $\begin{array}{c}\text { conform } \\
\text { ance }\end{array}$ & $\begin{array}{c}\text { conform } \\
\text { ance }\end{array}$ & $\begin{array}{c}\text { conform } \\
\text { ance }\end{array}$ & $\begin{array}{c}\text { conform } \\
\text { ance }\end{array}$ & $\begin{array}{c}\text { conform } \\
\text { ance }\end{array}$ & $\begin{array}{c}\text { conform } \\
\text { ance }\end{array}$ \\
\hline $\begin{array}{c}\text { Actual } \\
\text { conform } \\
\text { ation of } \\
\text { the rear } \\
\text { channel }\end{array}$ & $\begin{array}{c}\text { conform } \\
\text { ance }\end{array}$ & $\begin{array}{c}\text { conform } \\
\text { ance }\end{array}$ & $\begin{array}{l}\text { conform } \\
\text { ance }\end{array}$ & $\begin{array}{l}\text { conform } \\
\text { ance }\end{array}$ & $\begin{array}{l}\text { conform } \\
\text { ance }\end{array}$ & $\begin{array}{c}\text { conform } \\
\text { ance }\end{array}$ \\
\hline
\end{tabular}

It can be seen from table 4, after the mining of the above association rules, the production was sampled at $100 \mathrm{~mm}$ and $150 \mathrm{~mm}$ in open pine. As a precaution, a double sample T test for the sample material is also carried out. The results show that the two sample $\mathrm{T}$ test, when there is no significant difference between the weight and the circumference of the rear channel products, $\mathrm{P}=0.00$, because of $\mathrm{P} \leq 0.05$, it is believed that there is a significant difference in the drag resistance of the rear road products when the width of the two stage is $100 \mathrm{~mm}$ and $150 \mathrm{~mm}$, there is no significant difference between the results of the sampling in the front, and the results based on the mining of the interest association rules are consistent.

\section{V.SUMMARY}

In this paper, association rules mining is done through data transformation and sorting through Apriori algorithm through interest data association rules, so that equipment adjustment and parameter settings are verified, and the decision support degree of poor performance is given.

\section{REFERENCE:}

[1] MA Yong, ZHAO Xue-ming, SUN Bo. The Analysis Method of Web Log based on Apriori Algorithm.[A]. Computer security Specialized Committee of China Computer Society. Twenty-seventh National Symposium on computer security academic exchange [C].2012:3.

[2] Liu Li-gang, Zhong Rui,Yang Juan.Application of Apriori algorithm based on interest measure in data analysis of electronic medical records. Joumal of Jiangxi University of Science and Technology,2013,34(5):7376

[3] ZHOU Xin, SHA Chao-Feng, ZHU Yang-Yong, Another threshold of interest degree-association rules[J]. Computer research and development.2000, 37(5):627-633.

[4] Li-ming ZHU, Min ZHANG, Jin XU, Qiang ZHU and Shuai YANG, A process tracking system of quality parameters for dual channel forming machine, International Conference on Computer Mechatronics and Electronic Engineering,2016:39-43. 